\title{
DECISION-MAKING IN THE MANAGEMENT OF THE TAX AUTHORITIES ON THE BASIS OF INTEGRATED PERFORMANCE INDICATORS
}

\author{
Assistant Professor Oleksandr Redych, \\ University of The State Fiscal Service of Ukraine, Irpin, Ukraine
}

DOI: https://doi.org/10.31435/rsglobal_ijite/30042019/6454

\section{ARTICLE INFO}

Received 27 February 2019

Accepted 21 April 2019

Published 30 April 2019

\section{KEYWORDS}

tax administration;

productivity;

decision making;

quality management system.

\begin{abstract}
The paper highlights the results of applying the methodology of integral convolution of key indicators of economic efficiency of territorial subdivisions of the tax authority of the state: results of tax collection, productivity, cost, dynamics of indicators. The criteria for grouping of territorial tax divisions according to the values of the indicator of effectiveness for the purpose of making tactical and strategic management decisions are formed. The paper formulates recommendations on the use of the proposed approach in goalsetting when making managerial decisions based on the "sigma" management.
\end{abstract}

Citation: Oleksandr Redych. (2019) Decision-Making in the Management of the Tax Authorities on the Basis of Integrated Performance Indicators. International Journal of Innovative Technologies in Economy. 3(23). doi: $10.31435 /$ rsglobal_ijite/30042019/6454

Copyright: (C) 2019 Oleksandr Redych. This is an open-access article distributed under the terms of the Creative Commons Attribution License (CC BY). The use, distribution or reproduction in other forums is permitted, provided the original author(s) or licensor are credited and that the original publication in this journal is cited, in accordance with accepted academic practice. No use, distribution or reproduction is permitted which does not comply with these terms.

Introduction. The state implementation of key performance indicators.

In 2001, the State Tax Service of Ukraine (STSU) with the support of the International Bank for Reconstruction and Development (IBRD) has initiated project "Modernization Program of the State Tax Service of Ukraine" (MPSTS). Tracking the results of qualitative and quantitative changes in society caused by the implementation of the project, the degree of achievement of project objectives and fundamental changes associated with its implementation, carried out on the basis of the developed and agreed with IBRD key performance indicators (KPI).

In accordance with the obligation of STSU were calculated baseline and control values of KPI, that have been identified as required to track and recorded in Appendix to the Loan Agreement (the "Modernization of the State Tax Service of Ukraine - 1") on September 4, 2003 № 4698-UA between Ukraine and the IBRD. Monitoring KPI for 2001-2010, carried out company "GFK Ukraine". Results of monitoring indicators listed in Table 1 [1].

Table 1. Value indicators of progress MPSTS (2001-2010)

\begin{tabular}{|l|c|c|c|c|c|c|c|}
\hline Name of indicators \year & 2001 & 2005 & 2006 & 2007 & 2008 & 2009 & 2010 \\
\hline $\begin{array}{l}\text { (I1) Voluntary fulfilment of tax obligations } \\
\text { by the methodology of 2005-2006 }\end{array}$ & 54,5 & 74,7 & 86,8 & 88,9 & 81,6 & 90,6 & 91,8 \\
\hline $\begin{array}{l}\text { (I2)Voluntary fulfilments of tax obligations } \\
\text { by the methodology of 2007 }\end{array}$ & - & - & - & 64,1 & 64,7 & 57,1 & $39,2^{*}$ \\
\hline (I3)The cost of tax compliance & 56,1 & 53,8 & 59,4 & 63,8 & 60,2 & 61,1 & $51,2^{*}$ \\
\hline $\begin{array}{l}\text { (I4)The probability of detection of cases of } \\
\text { tax evasion by the method in 2007 }\end{array}$ & - & 8,7 & 5,0 & 6,4 & 7,0 & 4,2 & $6,7^{*}$ \\
\hline $\begin{array}{l}\text { I5) Quality performance features of STSU, } \\
\text { tax administration and taxpayer service }\end{array}$ & 33,6 & 56,9 & 57,5 & 66,1 & 62,3 & 60,5 & 62,0 \\
\hline $\begin{array}{l}\text { (I6) The integral criterion progress of the } \\
\text { MPSTS in 2007-2010** }\end{array}$ & - & - & - & 47,0 & 49,0 & 20,0 & 32,0 \\
\hline
\end{tabular}


* Statistically significant differences compared with the 2009 results

** Calculated by the author using indexes I2 - I4 on the methodology of convolution $(\mathrm{w}=0,25)$

Analysis of Table 1 makes it possible to analyze the dynamics of indicators of progress MPSTS. Obviously, the dynamics of generalized indicators of implementation MPSTS in 2010, has a rather ambiguous nature. There was a significant deterioration in voluntary fulfillment of tax obligations by the method in 2007 (by 17.9 percentage points) and increased burden of the cost of tax compliance (the indicator decreased by 9.9 percentage points). Index Voluntary fulfilments of tax obligations fell by individual entrepreneur, whose share in the total number of taxpayers in Ukraine is the most significant (91.6\% in 2010) and even the growth rate in the other groups did not prevent the negative dynamics of the overall indicator.

The reduction of the costs of tax compliance was observed in all groups of enterprises.

The integral indicator of progress MPSTS (2007-2010) that was calculated by the author according to the methodology convolution indicators also confirms that in 2010 the overall quality of functioning of DPS has not reached of the pre-crisis value (assuming $\mathrm{w}=0,25$ ).

It should be noted that the above results of the monitoring of the STSU are the results of the external evaluation, which in itself is a useful and important for strategic decision making, but they do not allow to analyze the causal relationship. In addition, key performance indicators which were considered, did not allow the quality and operating efficiency of STSU.

However urgent problem today is the lack of really existing system creating and monitoring the indicators of activities of STSU, and thus, built on the basis of that system corporate decision support system, operational risk management and overall quality of activities of subdivisions STSU.

The methodology of calculation indicators

It is known that for evaluating the quality of any economic process is important to choose the parameters that characterize its and identify endogenous and exogenous variables. It is logical evaluate the level of socio-economic development of the region from the efficiency of tax policy and the quality of activity of STSU. The quality of services provided by STSU for business environment of the region, the level of partnership can significantly affect the tax revenue. However, from the point of view of a head of STSU, the value of revenues depend on the tax base, which is a reflection of socio-economic development of the region. And as in the first and in the second case, the result is significantly influenced by the level of corruption that is determined, including the effectiveness of anti-corruption legislation (Fig.1).

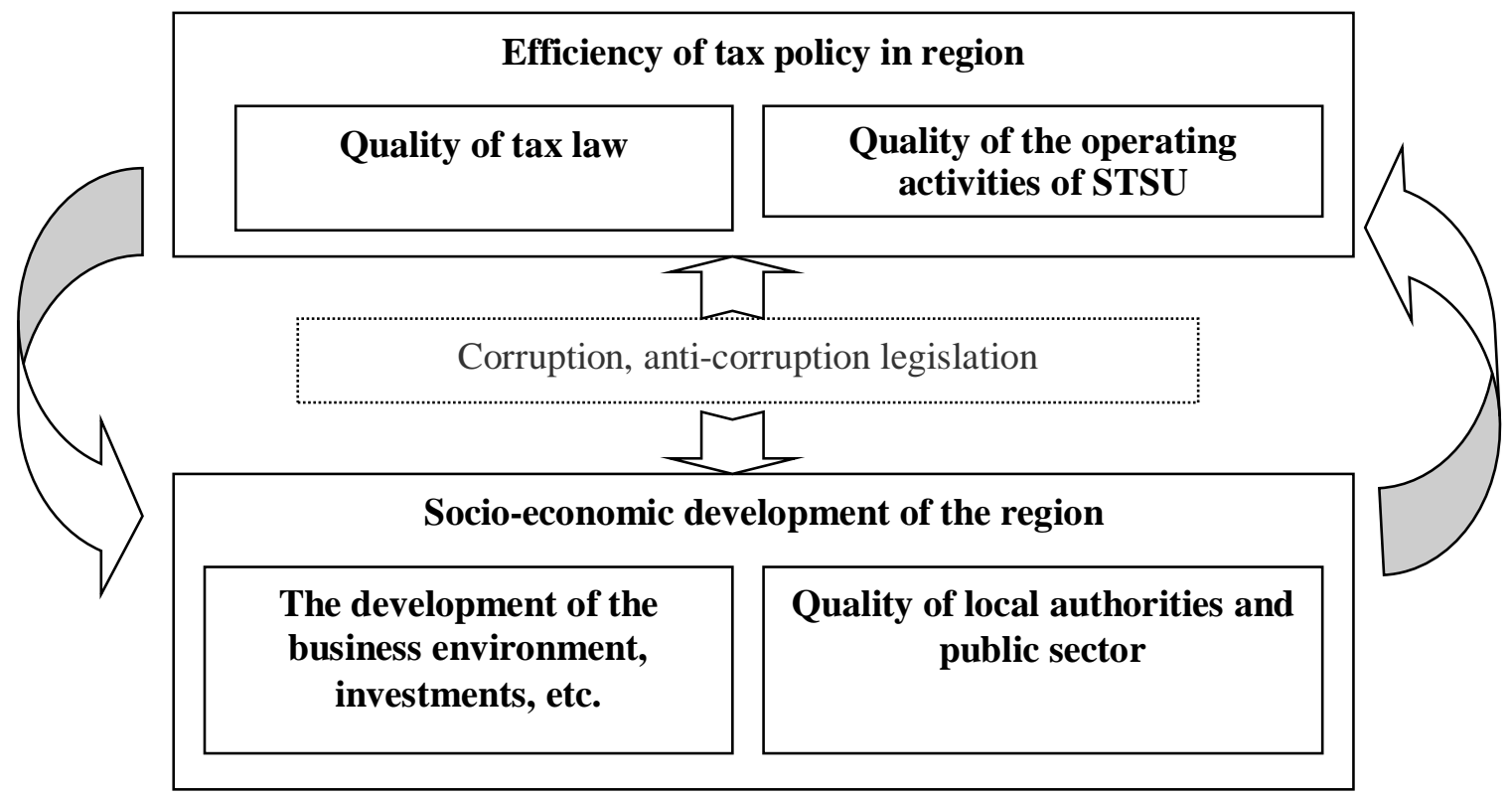

Fig.1. Interdependence of socio-economic development and the effectiveness of tax policy in region

In this paper as the main resultant indicator is taken the effectiveness of tax policy in the country (region), that considered as functional:

$$
\mathrm{F}=\mathrm{f}(\mathrm{Q}, \mathrm{E}, \mathrm{U})
$$

where: F - the level of efficiency of tax policy; Q - quality work of STSU (determined on the basis of internal data STSU in terms of effectiveness, quality operations, cost effectiveness, etc.) E - level of 
socio-economic development of the region; $\mathrm{U}$ - the external quality assessment activities of the STSU made by nongovernmental organizations on the agreed methodology.

Obviously, the tax policy in the country (region) can be considered as effective if indices Q, E, $\mathrm{U}$ have a positive trend.

Information resources modernized information system of STSU allow calculate statistics distribution of key indicators. Therefore, for tactical and strategic decision-making based on integrated criteria, that discussed below, may be used a method known as «optimization method on average». Due to the simplicity, enabling analysis of causal relationships, forming conclusions based on the economic content of indicators and built on them integral criteria or KPI, this method can be easily integrated into the information-analytical systems STSU. Also in the future on the basis of approved indicators in the STSU can implement decision support systems (DSS) and intelligent technologies that are based on neural networks, fuzzy sets, pattern recognition, classification, clustering and so on [2-4].

In applying the method optimize on average no need determine the probabilities indicators (criteria, key performance indicators) and use some statistical characteristic, namely mathematical expectation. A value of each KPIk depends on a vector of strategies (possible solutions for its improvement) $\mathrm{x}$, an array of determined parameters A (tax law, modalities business, etc.) of options realizations $\mathrm{y} 1, \mathrm{y} 2, \ldots . .$. , yi of random factors $\mathrm{Y} 1, \mathrm{Y} 2, \ldots .$. Yi (the level of violations of the law by taxpayers, tax receipts, etc.) (2):

$$
K P I_{k}=K P I_{k}\left(x, A, y_{1}, y_{2}, \ldots \ldots, y_{i}\right),
$$

Then the mathematical expectation $\mathrm{M}\left[\mathrm{KPI}_{\mathrm{k}}\right]$ can be written as the integral (3):

$$
\begin{aligned}
& F_{k}=M\left[K P I_{k}\right]=\iiint_{i}\left(A, x, y_{1}, y_{2}, \ldots ., y_{i}\right) f\left(y_{1}, y_{2}, \ldots, y_{i}\right) d y_{1}, d y_{2}, \ldots, d y_{i} \\
& =F_{k}(x, A, B),
\end{aligned}
$$

where: $\mathrm{F}_{\mathrm{k}}$ - value mathematical expectation k-th KPI; B - an array of well-known statistical characteristics of random variables $\mathrm{Y}_{1}, \mathrm{Y}_{2}, \ldots ., \mathrm{Y}_{\mathrm{i}} ; \mathrm{f}\left(\mathrm{y}_{1}, \mathrm{y}_{2}, \ldots \ldots ., \mathrm{y}_{\mathrm{i}}\right)$ - the law of distribution of random variables $\mathrm{Y}_{1}, \mathrm{Y}_{2}, \ldots ., \mathrm{Y}_{\mathrm{i}}$.

In applying the method to optimize on average optimal strategy is chosen from the set of admissible strategies that maximizes the value of mathematical expectation integral index $I=M[F]$ and calculated on the basis of all KPIk. Other words the optimal strategy management authority STSU must satisfy the following condition (4):

$$
\bar{I}=F(x, A, B)=\max F(x, A, B)=\max _{x \in X} M\left[I\left(A, x, y_{z}, y_{z}, \ldots, y_{i}\right)\right] .
$$

When using the optimal strategy in many organs STSU, for example in the regional (oblast), district, city, or national levels, will on average the best result of their operation.

For calculate the indicators, integral criteria and key performance indicators that are further in the text, was used additive method of convolution parameters (5):

$$
I_{k}=\max \sum_{i=1}^{n} \pm w_{i} q_{i} \quad \sum_{i=1}^{n} w_{i}=1, \quad 0<w_{i}<1
$$

where: $\mathrm{I}_{\mathrm{k}}$ - integral criterion; $\mathrm{q}_{\mathrm{i}}$ - normalized index; $\mathrm{w}_{\mathrm{i}}$ - weights.

For normalization indicators, which growth indicates to improve the situation, was used formula (6):

$$
q_{i}=q_{i}\left(x_{i}\right)= \begin{cases}0, & \text { при } \mathrm{x}_{\mathrm{i}} \leq \min _{\mathrm{i}} \\ \left(\frac{x_{i}-\min _{i}}{\max _{i}-\min _{i}}\right) \times 100, & \text { при }<\mathrm{x}_{\mathrm{i}} \leq \min _{\mathrm{i}} \\ 100, & \text { при } \mathrm{x}_{\mathrm{i}}>\max _{\mathrm{i}}\end{cases}
$$

For normalization indicators, decrease of which indicates to improve the situation, was used formula (7): 


$$
q_{i}=q_{i}\left(x_{i}\right)= \begin{cases}100, & \text { при } \mathrm{x}_{\mathrm{i}} \leq \min _{\mathrm{i}} \\ \left(\frac{\max _{i}-x_{i}}{\max _{i}-\min _{i}}\right) \times 100, & \text { при }<\mathrm{x}_{\mathrm{i}} \leq \min _{\mathrm{i}} \\ 0, & \text { при } \mathrm{x}_{\mathrm{i}}>\max _{\mathrm{i}}\end{cases}
$$

Below are the names and contents of the main indicators that was tested in the calculations [5]. Indices $\mathrm{i}, \mathrm{j}$ in terms of mean $\mathrm{i}$-th unit of the STSU in the $\mathrm{j}$-th region (region), Wij - weights. It is possible to calculate the parameters for all subdivisions at all levels of STSU center, region, district, city and etc [5].

The integral criterion of the quality activity of STSU subdivisions $\left(\mathbf{I q} \mathbf{a}_{\mathbf{i j}}\right)$ - general criterion, calculated on the basis of quality criteria operating activity, effectiveness, and others, including the level of a violation of law by STSU employees;

The integral criterion of effectiveness activity of STSU subdivisions $\left(\mathbf{I e a}_{\mathbf{i j}}\right)$ - index characterizing the effectiveness of tax collection and payments and cost-effectiveness of the STSU subdivisions, their dynamics;

The integral criterion of quality operational processes of STSU subdivisions (tax administrating) $\left(\mathbf{I q o p}_{\mathbf{i j}}\right)$ - an criterion calculated by indicators of the main operational processes and characterizes the overall quality of operations of STSU subdivisions;

The integral criterion violations legislation by STSU employees (Ivle $\mathbf{I}_{\mathbf{i j}}$ ) - integral index, which was calculated based on the actual indicators of violations of legislation by workers in the regions and by qualities preventive work to reduce the number of violations;

The integral criterion of socio-economic development (Ised $_{\mathrm{ij}}$ ) - an index that characterizes the state of socio-economic development of regions and calculated based on the indicators of the State Statistics Committee of Ukraine;

The integral criterion of the quality of activity of STSU subdivisions, calculated NGOs $\left(\mathbf{I q a n}_{\mathbf{i j}}\right)$ - indicator, calculated on the basis of survey made by non-government institutions and describes the activities STSU subdivision on the estimation that provided by taxpayers at an agreed methodology. For this criterion can be used for example the monitoring of key indicators by GFK Ukraine (table.1);

The integral criterion efficiency of tax policy in regions ( Ietp $_{\mathbf{i j}}$ ) - an indicator describes the effectiveness of tax legislation, tax system and quality activity of STSU subdivisions, their impact on the socio-economic development of the region, taking into account assessments by independent institutions and civil society. May be calculated on the basis of indicators $\mathbf{I e a}_{\mathbf{i j}}$, Ised $\mathbf{I s}_{\mathbf{i j}}$, $\mathbf{I q a n}_{\mathrm{ij}}$.

Figure 2-3 shows the general scheme of calculating The integral criterion of effectiveness activity of the STSU (Ieaij) and of The integral criterion efficiency of tax policy (Ietpij).

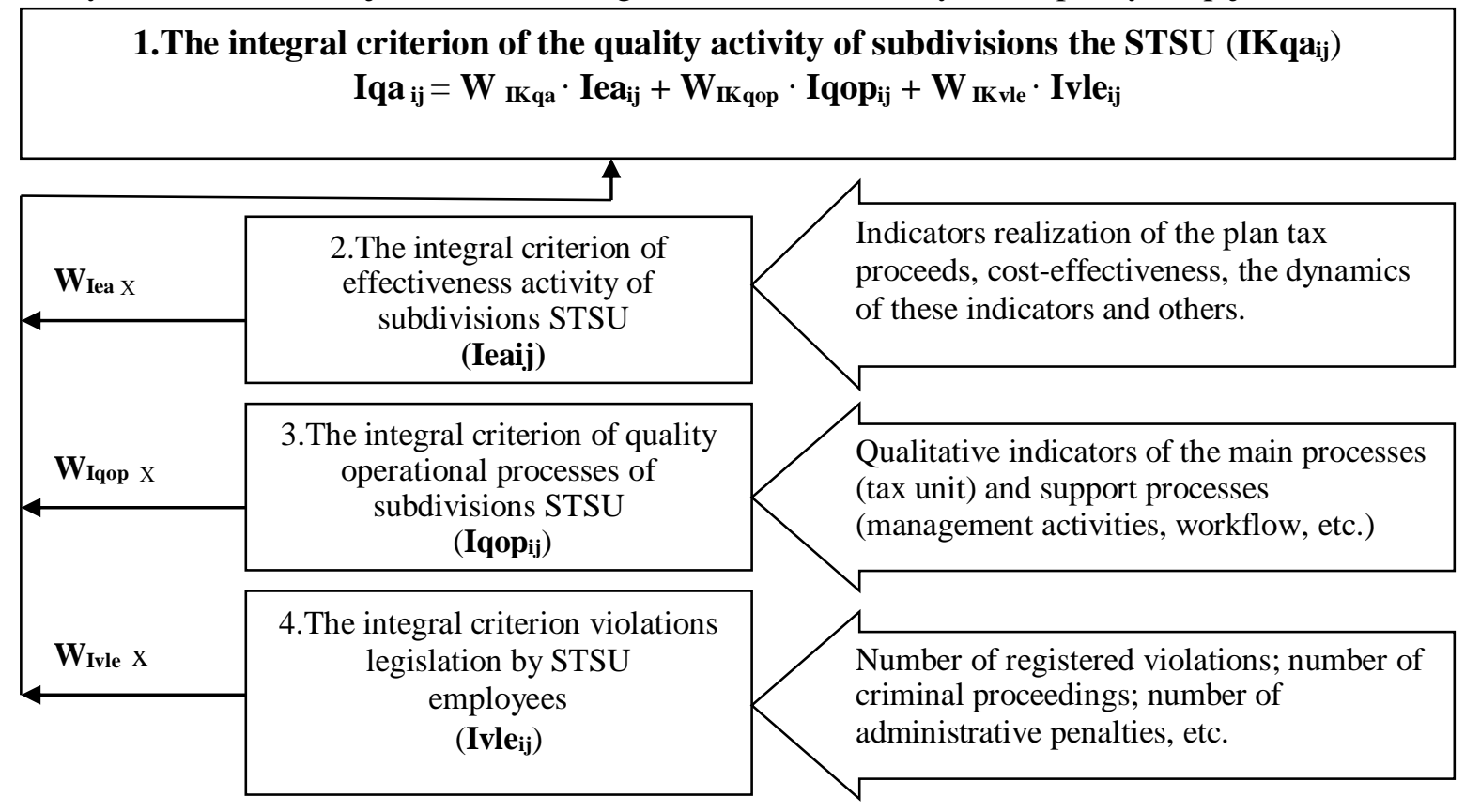

Fig. 2. The general scheme of calculating the integral criterion of effectiveness activity of STSU subdivision $\left(\boldsymbol{I K q a}_{i j}\right)$ 


\section{The integral criterion efficiency of tax policy in regions (Ietp $\left.\mathrm{ij}_{\mathrm{ij}}\right)$ \\ IeIII $_{i j}=W_{I K q a} \cdot$ Iqa $_{i j}+W_{\text {IKsed }} \cdot$ Ised $_{i j}+W_{I K q a n} \cdot \operatorname{Iqan}_{i j}$}
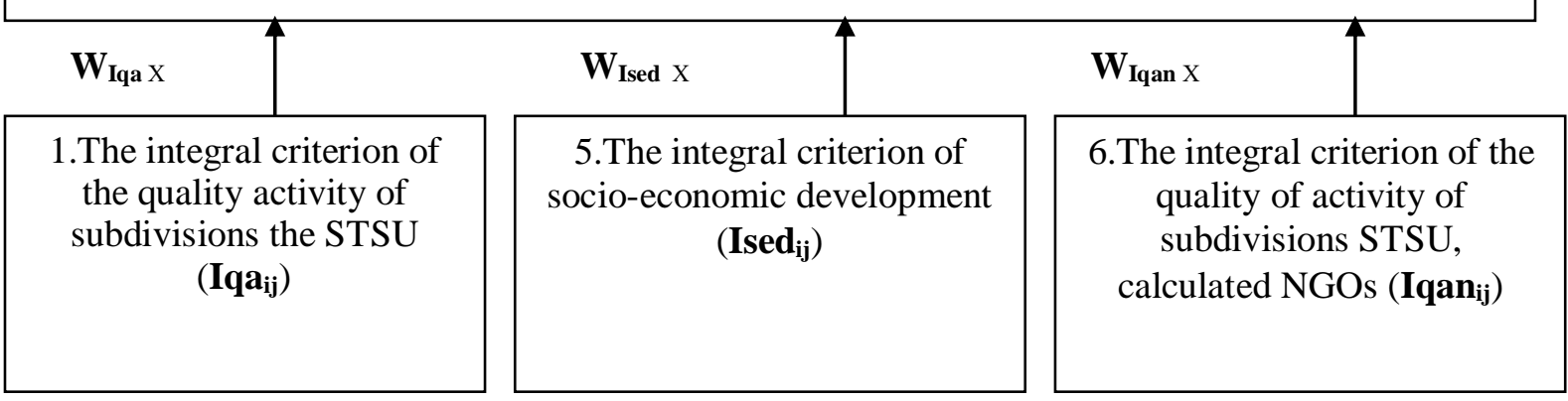

Fig. 3. The general scheme of calculating the integral criterion efficiency of tax policy in regions (IKetp $i j)$

Research results. Table 2 shows the calculated values integral criteria that were considered. Weights were determined by experts. If it is was impossible to determine the level of influence indicator, were used equal weights.

For calculate the integral quality criterion operational processes of STSU was used statistical bulletin STSU by 01.10.2010.

For calculate the integral criterion of socio-economic development of regions was used information about the socio-economic development of Ukraine in 2009-2010, (regions) [6].

For calculate the integral criterion violation legislation of STSU employees used the data from report "Assessment of regional departments of Security STSU" for January - June 2010.

As can be seen from Table 2, the integral criterion efficiency of tax policy (Ietp) has an average value by regions of Ukraine 52.66, indicating a considerable reserve. This low level of effectiveness of tax policy explains low level of socio-economic development in the regions (Ised=29.18), of low-quality work of DPS (Iqa $=62.54$ ), of high levels of violations of law STSU employees (Ivle $=61.73$ ).

Computed by author on the data GFK Ukraine The integral criterion of the quality activity STSU (Iqan $=64.98$ ) is also consistent with calculations on the integral criterion Iqop=63,63, that was computed by the data of STSU (Tabl.2).

Table 2. The calculated integral criteria and basic statistics of their distribution

\begin{tabular}{|c|l|c|c|c|c|c|}
\hline$\#$ & \multicolumn{1}{|c|}{ Name of indicators } & Label & Average & $\begin{array}{c}\text { Mean- } \\
\text { square } \\
(\delta)\end{array}$ & max & $\min$ \\
\hline 1 & $\begin{array}{l}\text { The integral criterion efficiency of } \\
\text { tax policy* (F) }\end{array}$ & Ietp & 52,66 & 4,46 & 67,21 & 46,66 \\
\hline 2 & $\begin{array}{l}\text { The integral criterion of the quality } \\
\text { activity* (Q) }\end{array}$ & Iqa & 62,54 & 6,33 & 73,78 & 48,49 \\
\hline 3 & $\begin{array}{l}\text { The integral criterion of the quality } \\
\text { activity calculated NGOs ** (U) }\end{array}$ & Iqan & 64,98 & 4,24 & 70,20 & 58,40 \\
\hline 4 & $\begin{array}{l}\text { The integral criterion of socio- } \\
\text { economic development } *(E)\end{array}$ & Ised & 29,18 & $\mathbf{1 2 , 1 0}$ & 78,64 & 14,66 \\
\hline 5 & $\begin{array}{l}\text { The integral criterion of } \\
\text { effectiveness activity (Ukraine) } *\end{array}$ & Iea & 64,99 & 7,15 & 87,61 & 33,93 \\
\hline 6 & $\begin{array}{l}\text { The integral criterion of quality } \\
\text { operational processes } \\
\text { (tax administrating)* }\end{array}$ & Iqop & 63,63 & 6,82 & 78,54 & 48,37 \\
\hline 7 & $\begin{array}{l}\text { The integral criterion violations } \\
\text { legislation by STSU employees } *\end{array}$ & Ivle & 61,73 & $\mathbf{1 6 , 2 1}$ & 92,64 & 22,70 \\
\hline
\end{tabular}

*Computed by author on the data statistical bulletin STSU by 01.10.2010.

**Computed by author on the data GFK Ukraine by 31.05.2011. 
For example let's see the results of calculating The integral criterion of the effectiveness of the STSU (Iea), which was calculated on data 462 STSU subdivisions. Criterion characterizes on average the performance of the STSU subdivisions, achievement assigned tasks of collecting payments, percentage deviation from the set of tasks, their dynamics, economic efficiency - and expenses of performance $($ Iea $($ average $)=64.99$, Table 2 ) .

Table 3. The rules of grading of STSU subdivisions in terms of effectiveness

\begin{tabular}{|c|l|c|}
\hline $\begin{array}{c}\text { Number of } \\
\text { group }\end{array}$ & \multicolumn{1}{|c|}{ Group of DPS in terms of effectiveness of } & Values of IKea $\mathrm{a}_{\mathrm{ij}}$ \\
\hline 1 & Group high of effectiveness & Iea $_{\mathrm{ij}}>72$ \\
\hline 2 & Group moderate effectiveness & $58<\mathrm{Iea}_{\mathrm{ij}}<72$ \\
\hline 3 & Group low of effectiveness & Iea $_{\mathrm{ij}}<58$ \\
\hline
\end{tabular}

Table 2 shows the main characteristics distribution criterion Iea and on Fig. 4 shows its histogram, which indicating its compliance with the normal law. Based on statistical distribution parameters (Table 2, line 5) were formed rules of grading of STSU subdivisions in terms of effectiveness. To test was taken average value Iea $=65.0$, Mean-square $=7$ and were identified three main groups of STSU subdivisions.

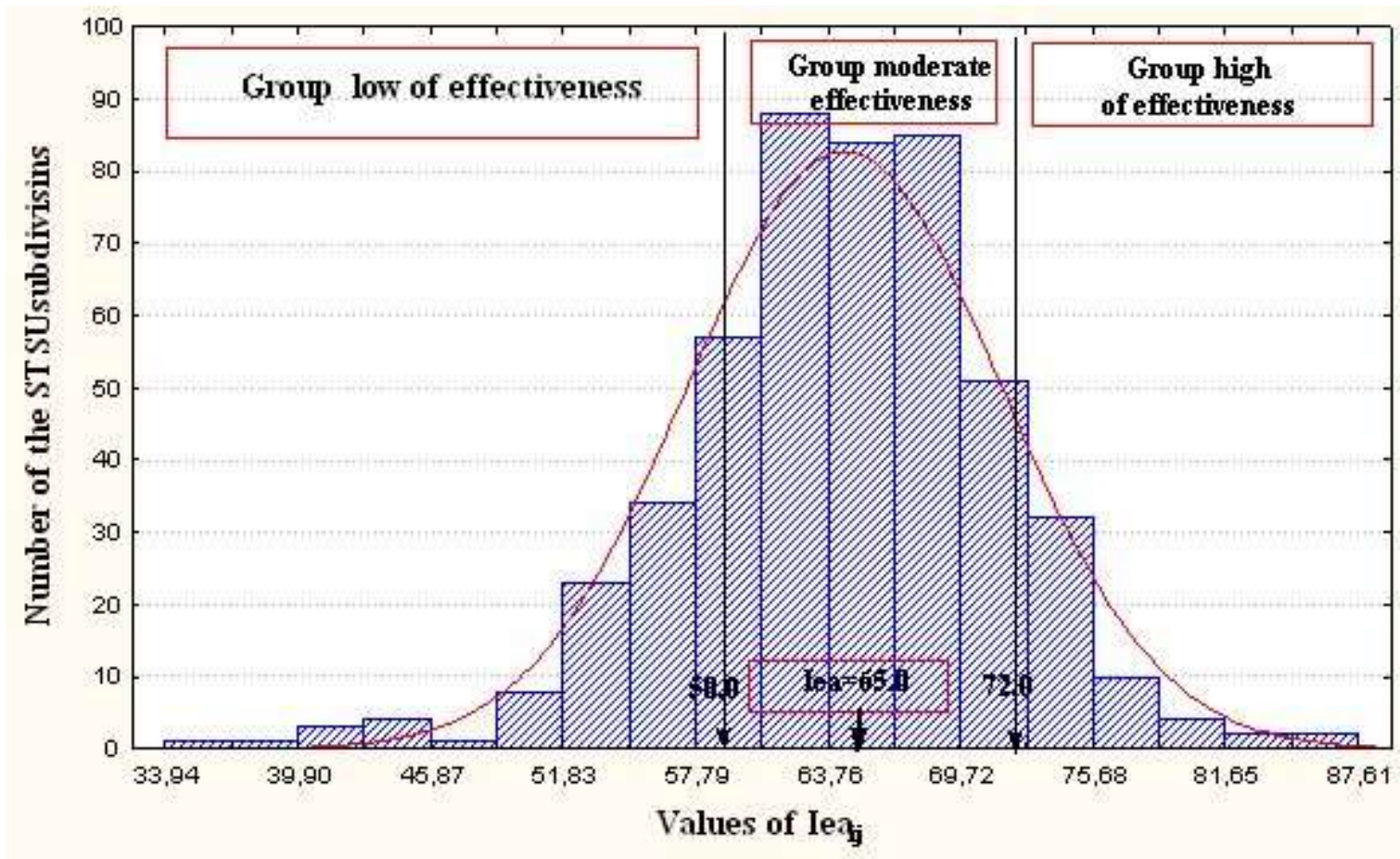

Fig. 4. Histogram distribution of the calculated values of The integral criterion of effectiveness activity of STSU subdivisions (IKea $\left.{ }_{i j}\right)$

The results of classification of the STSU subdivisions by the values of integral performance criteria given in Table. 4. In the 3rd group low of effectiveness falls 74 of STSU subdivisions, that is $16 \%$ of the total number of STSU subdivisions. The total sum non-fulfilment of the established objectives for tax revenues to this groups subdivisions is 9225628 thousand grivnas or $53.14 \%$ of the total non-fulfilment of assigned tasks for collect to the General Budget Fund. To the group moderate effectiveness falls 331 of STSU subdivisions, or they $71.5 \%$, and this confirming the normality of the distribution of the values of this integral criterion.

It should be noted that defining of the laws distributions for others criteria and indicators - the next necessary step in implementation this method. It will provide forming and choice strategies in decision making to improve the quality of activities of STSU in the in terms of risk managements.

Obviously, the STSU leadership would need to has pay special attention to the third group of the 74 subdivisions for elucidate the reasons non-fulfilment of the established objectives for tax 
revenues, identify indicators that reflect the effect of the main factors, made an action plan to improve and develop based on the analysis of causation. However, to advisable to explore and illuminate the experience of 57 units of DPS first group, in particular the impact on the overall qualities of the activities of the STSU of levels laws violations DPS employees and others indicators.

For instance, subdivisions of the third group, usually have a lower rate of income dynamics, productivity and economic efficiency, a high level of violations of workers DPS legislation, significant sums non-fulfilment of the established objectives for tax revenues. So at the central level of STSU may be formed target criteria of effectiveness, quality of activities in general and certain groups of subdivisions. Strategies to achieve the targets can be based on the identification of intellectual and material resources to improve specific indicators, reduce the risk of adverse outcomes.

Table 4. The results of the classification of the STS subdivisions by the values of The integral criteria of effectiveness activity $\left(\mathbf{I} \mathbf{e a}_{\mathrm{ij}}\right)$

\begin{tabular}{|c|c|c|c|c|c|}
\hline \# & Values of Iea $_{i j}$ & $\begin{array}{c}\text { Number of the } \\
\text { STSU } \\
\text { subdivisions }\end{array}$ & $\begin{array}{c}\text { Proportion of } \\
\text { the STSU } \\
\text { subdivisions in } \\
\text { total, } \%\end{array}$ & $\begin{array}{l}\text { Total sum non- } \\
\text { fulfilment of the } \\
\text { established } \\
\text { objectives for tax } \\
\text { revenues, } \\
\text { (thousand grivnas) }\end{array}$ & $\begin{array}{l}\text { Proportion of the sum } \\
\text { non-fulfilment of the } \\
\text { established objectives } \\
\text { for tax revenues in } \\
\text { total sum non- } \\
\text { fulfilment for } \\
\text { Ukraine, } \% \\
\end{array}$ \\
\hline 1 & $\begin{array}{c}\text { Iea }_{\mathrm{ij}}>72 \\
\text { (Group high of } \\
\text { effectiveness) }\end{array}$ & 57 & 12,3 & - & 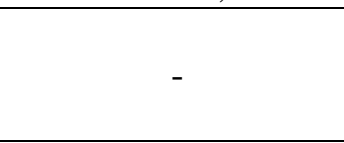 \\
\hline 2 & $\begin{array}{c}58<\mathrm{Iea}_{\mathrm{ij}}<72 \\
(\text { Group moderate } \\
\text { effectiveness) }\end{array}$ & 331 & 71,5 & 8132563 & 46,86 \\
\hline 3 & $\begin{array}{c}\text { Iea }_{\mathrm{ij}}<58 \\
\text { (Group low of } \\
\text { effectiveness) } \\
\end{array}$ & 74 & 16 & 9225628 & 53,14 \\
\hline & Total & 462 & 100 & 17358191 & 100 \\
\hline
\end{tabular}

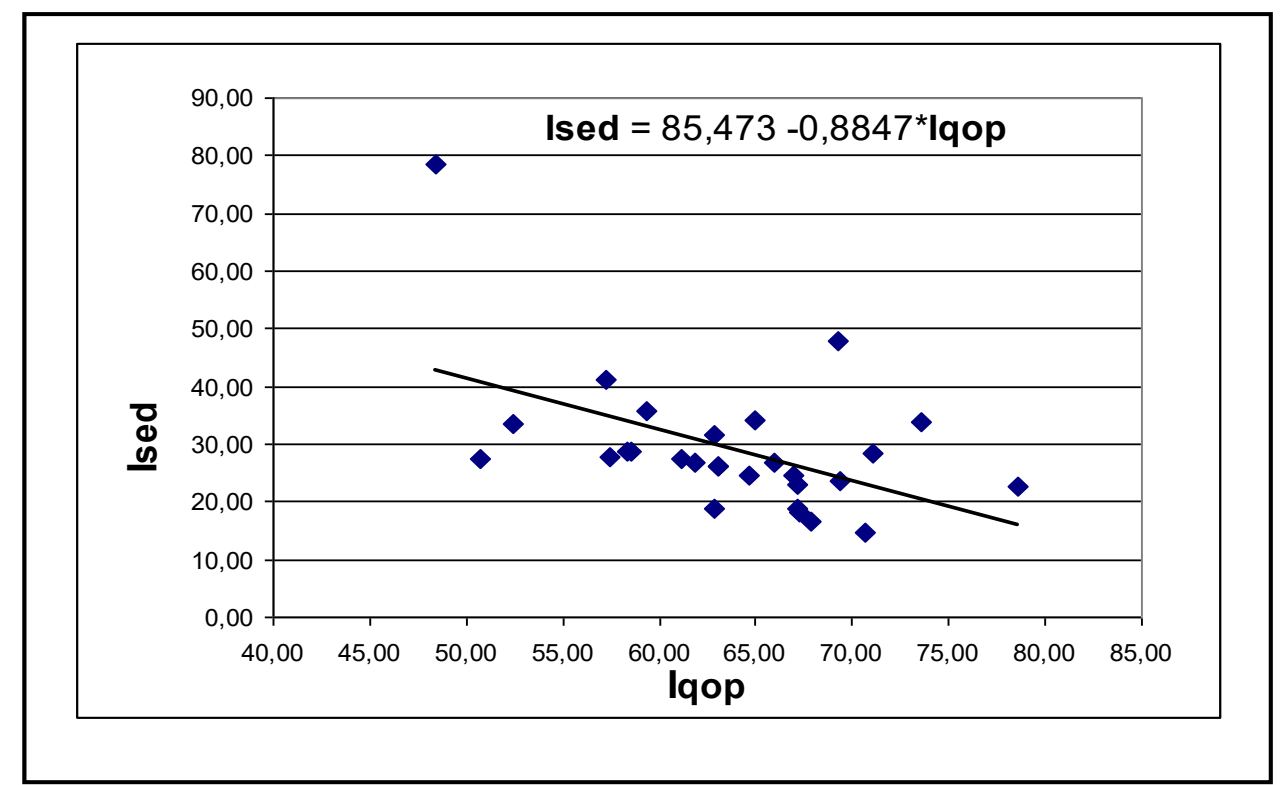

Fig. 5. Correlation between The integral criterion of socio-economic development (Ised) and The integral criterion of quality operational processes (Iqop) in a regional context. 


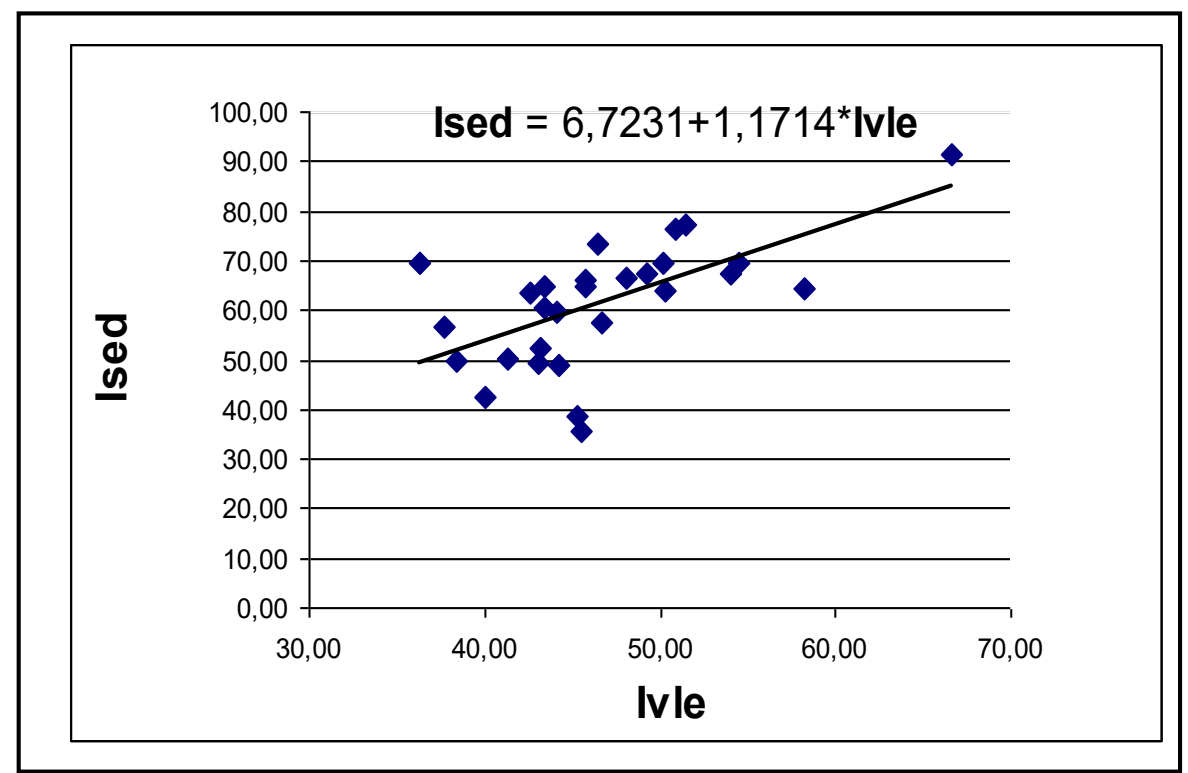

Fig. 6. Correlation between The integral criterion of socio-economic development (Ised) and The integral criterion violations legislation by the STSU employees (Ivle) in a regional context.

It is important to verify the logical inter-dependencies indicators. In this regard, the author was tested hypothesis of a direct relationship of quality activities of the STSU and the socio-economic development of regions. The result of the analysis according to the State Statistics Committee of Ukraine and the STSU on 10.01.2010, has shown unexpected results.

Between the level of socio-economic development and the quality activities of the STSU is a negative correlation, when between the level of effectiveness of the STSU - a significant direct correlation. Between the level of the quality activities of the STSU and the level of violation legislation of STSU employees - also is a negative correlation (Fig. 5,6,7).

Actually at this stage of the research is need for in-depth investigation of the causes of such dependencies, for which calculations should be made for a few periods and explored they dynamics.

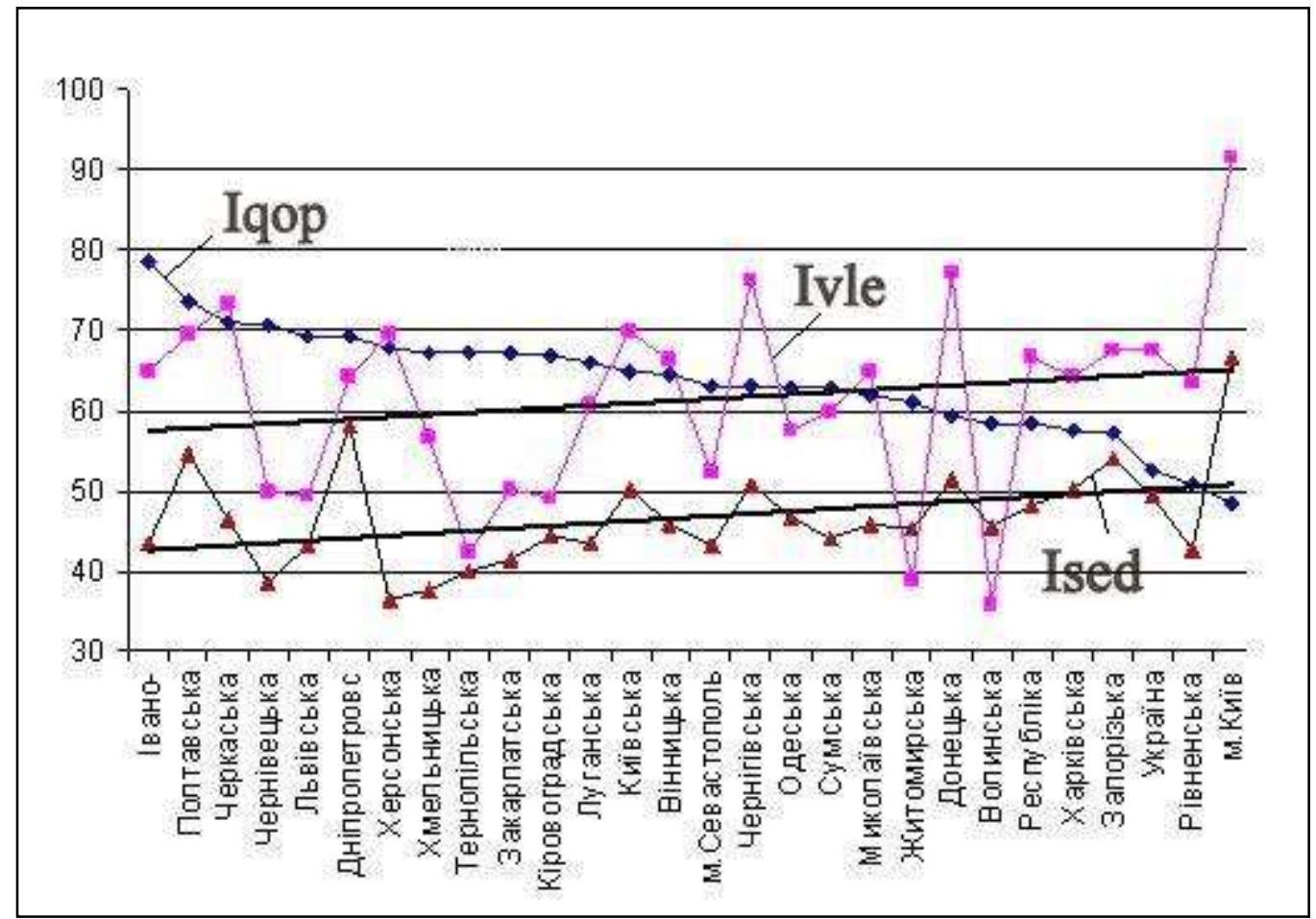

Fig. 7. Charts values of integral criteria Iqop, Ised, Ivle when values of Iqop sorted by decrease.

Conclusions. Preliminary conclusions that can be drawn from the application of the methodology and analysis interdependencies of the integral criteria: 
1. Improving the situation of violation of legislation STSU employees leads to an increase in socio-economic development (ie economic situation is improving). On average, the improvement on $1 \%$ situation of violation legislation of STSU employees on average by $1.17 \%$ improving socioeconomic situation of the region.

2. Negative correlation quality operational processes and of violations legislation of STSU employees can be explained by influence the level of corruption in the STSU on the formation indicators of quality, or of the level of legal education business and other factors, that needs further investigation.

3. Implementation in the management activities of STSU key performance indicators (Key Performance Indicator), Indicators of quality, economic efficiency, productivity, the dynamics of these indicators are relevant at this stage of reforming the tax system in Ukraine and will allow implement a system of effective motivation employees;

4. When filling information systems STSU indicators of socio-economic development, establishing exchange of economic information from the State Statistics Committee, State Treasury of Ukraine, application of the methodology of key indicators will improve the quality operational processes, tax forecasting, analysis of the use a tax potential, the implementation of tax policy in the regions and the country.

\section{REFERENCES}

1. The Interim report providing services by foreign enterprises "GFK Ukraine" under contract number 63M on 28 February 2011 as the results of the calculation of key indicators of progress of the project of modernization of the State Tax Service of Ukraine-1 in 2010. May 31, 2011;

2. Вітлінський В.В. Редич О.В. Методологічні основи управління ризиками у адмініструванні податків. Вісник НУДПСУ, №3 (46), 2009, с.107-113.

3. Редич О.В. Концептуальні основи впровадження системи оцінювання результативних показників діяльності органів ДПС. Модернізація ДПС України у контексті інноваційного розвитку: матеріали наково-практичного семінару. - Ірпінь: Національний університет ДПС України. 2010. -222 С. с. 58-65.

4. Guidelines on the definition of performance indicators budget program approved by the Ministry of Finance of Ukraine on October 27, 2009 N1252 "On budget program performance indicators."

5. Зведений звіт про застосування методології інтегральних критеріїв при оцінці процесів адміністрування податків та результативних показників діяльності органів ДПС України. ДРМ ДПС. - 2011 р, С54.

6. Державна служба статистики. Official site of the State Statistics Service of Ukraine. URL: http://www.ukrstat.gov.ua/ 